\title{
THE ROLE OF OPEN AND DISTANCE HIGHER EDUCATION IN DETAINEES IN GREEK DETENTION FACILITIES
}

\author{
CharitiniLinardatou[xlinardaton@yahoo.gr],Evangelia Manouson [manousong@gmail.com],Hellenic Open \\ University, Parodos Aristotelous 18, 26 335, Patra, Greece
}

\begin{abstract}
The purpose of this article is to present the results of the qualitative research conducted in Detention Facilities in Greece in connection with the preparation of the thesis (Linardatou, 2012). This is a case study of two prisoners attending Open Universities. The study concerned the characteristics and peculiarities of Open and Distance Education to Greek prisoners in detention facilities and the role of the Hellenic Open University (HOU) in higher education. The use of research tools such as telephone interviews and interviews with the use of a written questionnaire revealed the following information: In detention centres in Greece in 2012 there are two detainees-students studying together. HOU provides educational opportunities to prisoners but in its educational policy there is no strategy for the prisoners' distance education. The article concludes with suggestions for improving the HOU policy towards socially excluded people such as prisoners.
\end{abstract}

Keywords: Prisoners, Correctional Prisoners, Correctional Education, Education, Lifelong Learning, Second Chance Schools, Higher Open and Distance Education, Hellenic Open University.

\section{Introduction}

The rhetoric developed in recent years according to Castells (1996, as cited in Sianou-Kirgiou, 2009, p.236) is based on the assumption that the development of lifelong education is a prerequisite for the creation of the society of knowledge as knowledge is considered to be the key factor for economic progress and innovation in all spheres of human life.

Giossos, Mavroidis and Koutsouba (2008) point out that, as the trend of modern society is the search for flexible forms of education, such as distance education, which will meet the need for Lifelong Learning (L.L.), the research interest is enhanced for the possibility it provides to socially excluded people, such as prisoners, in L.L. through distance education.

The Hellenic Open University (HOU) is the chief provider of L.L., which - through Open and Distance Education (ODE) - provides a second chance to people who have been deprived of their access to higher education. Moreover, its participation in the program "Lifelong Learning Centres - National Range Programs \& Local Range Programs" strengthens its role in providing adult education and lifelong learning. (HOU, 2012).

The practice of open and distance education in higher learning of Greek Detention Facilities prisoners is the research scope of this paper. The educational opportunities offered to prisoners by the HOU are also a field of research and in particular the investigation of whether they are "open". To configure an as much deeper perspective as possible, and given the lack of data on the application of open and distance education at the Penitentiary institutions in Greece, the research interest focused on distance education provided at Detention Facilities of European 
countries, as well as the exploration of the education policy applied for prisoners by Open Universities, such as the Open University of the United Kingdom (OU/UK). Exploring the Greek and international literature it became apparent that in Greece there are no studies on distance education to prisoners who attend Open Universities.

Moreover, the survey at the Hellenic Open University (HOU) website did not reveal any information that would identify its educational policy regarding socially excluded people (e.g. prisoners). On the contrary, in the Open Universities of Europe there is a fierce debate about this issue (Salane, 2008; Wilson, 2010; Watts, 2010; Adams \& Pike, 2008; Pike, 2010). Information search on the United Kingdom Open University website gave us plenty of information on education in prisons in England. What is more, through the investigation of the European Prison Education Association (EPEA) site, an annex of which also exists in Greece, we have found that there are articles related to the education of prisoners. The prisons of England and Ireland as well as prisons in the Nordic countries are particularly active on the subject of their education (Bateman, 2010; Morgan \& Kett, 2003; Keogh, 2003; Chr Breivik, 2010).

\section{The setting of the problem}

The special feature of Open Education is flexibility. For this reason, according to Keegan (2000), Open Education could also be called flexible education, which has applicability in both "open" and "closed" systems of education in the sense that they have time limits for enrolment and delivery of work or exclude students for some reason.

A fundamental feature of these open systems of higher education is the philosophy of "openness" in education according to which education is a human right and people should be able to enjoy it throughout their lifetime, having educational opportunities on the one and ensuring access to higher education on the other (Lionarakis \& Lycourghiotis, 1998, p.30).

HOU provides exclusively distance education and its operation is based on the core philosophy of "open" systems of education which is, according to Lionarakis and Lycourghiotis (1998), "the creation of educational opportunities and access insurance".

HOU has been involved in innovative projects such as the program Grundtvig «Eliminating Language Barriers in European Prisons through Open and Distance Education Technology» with the aim to design and develop the e-learning course, with regard to the teaching of Greek as foreign language at beginner level for prison staff members in European countries, in order to be able to communicate with Greek prisoners (Eliminating Language Barriers in European Prisons, 2007).

Costelloe, Langelid, Hammerschick and Matt (2011, p.6) point out that "in the countries of the European Union there is broad consensus that education plays a positive and big role in recovery, and contributes significantly to the successful reintegration of prisoners into society." The importance of adult education in the education of prisoners and the implementation of distance learning as a flexible teaching method was discussed in the Council of Ministers (1989) and was recognized in Recommendation (R89) 12. (CoE, 1989, Fri 5.7, p.24).

\section{Distance education of prisoners in Greece}

The access to HOU of persons deprived of their social and political rights such as prisoners becomes of particular importance, since the Greek state has arranged for their lifelong education with the establishment of the Second Chance Schools (SCS) in Detention (N. 2525/97). In SCS prisoners have a second chance during a period of two years to attend training programs, through 
which they receive high school education certification (Institute of Adult Continuing Education, Second Chance Schools, 2012).

So according to the current legislation educating prisoners in Greece is confined in secondary education. With regard to access to higher education there is no specific regulation in the recent Life Long Learning (LLL) law (Bill 3879 / 09.21.2010) and also in the Correctional Code (Bill 2776/1999) there is no legislation on the application of distance learning (DL).

In the above discussion on the prospects of Life Long Learning of prisoners and in particular with regard to their access to higher education through distance education, it would be worth pointing out the elements that "ignited" our interest in people experiencing social exclusion in prisons.

The first element is the actual image of the Detention Facilities, which is characterized by overcrowding. Overpopulation in Greek prisons is a major problem which has troubled the Greek state as well. In the report of the Select Committee (2010, p.11) on the examination of the penitentiary system of the country and the living conditions of prisoners the spotlight was the increase in their number, the challenging conditions of detention, the economic crisis, poverty and the post-release 'suffering' they have to deal with.

The second element concerns a republication in "Sunday Ethnos" newspaper stating that a 30year old prisoner at the Women's Prison in Eleonas, Thebes has managed to "break" the chains of prison after sitting for the national university-entrance exams from within prison and succeeded in passing at the Florina Technological School, in the department of "Trade and Quality Control of Agricultural Products". According to the publication, the basic principle adopted by the nine professors of the Florina Technological School is that "every person is worth having a second chance in their life" and for this purpose they themselves alternately come every six months to help the incarcerated inmate inside jail in order to help her continue her studies (Almaliotou-Kalabaliki, 2011).

In light of the above publication but also of the outcome of the Ombudsman according to which in Greek prisons there are no monitoring programs of higher education (e.g. attendance at HOU) (Walnut \& Fytrakis 2011, p.221) the following conclusion yields: In Detention Facilities in Greece despite the difficult circumstances of overcrowding, there are cases of prisoners who manage to overcome the barriers of exclusion experienced in prison and continue their studies in higher education. It is important that there are higher education institutions which support the prisoners' efforts and, furthermore, that their efforts are recognized and rewarded by the Greek state.

\section{Empirical research: Case Study distance education in Greece}

The research questions that this article negotiates are the following: Are there prisoners studying at HOU? And if so, what are the characteristics of the distance education they receive? What are the difficulties in its implementation? Why did prisoners choose to study at HOU?

Research on the implementation of programs of higher Open and Distance Education in prison in Greece, aims at identifying the role and characteristics of this practice as well as the emergence of views of prisoners attending an Open University, so as to contribute to the fight against social exclusion experienced by prisoners.

To study in depth the goal of the research the application of Case Study was deemed appropriate because it is a well-established research strategy, where the focus is on a case (which is interpreted very broadly in order to include the case of a single individual, a group, an environment, an 
organization etc.) itself, while also taking into account its context. Typically, it includes multiple methods of data collection (Robson, 2010, p.211).

In this research, the data collection methods employed are semi-structured telephone interviews, questionnaires and, to check validity and reliability, triangulation. To better organize and coordinate the research the recording of all events and talks in a diary followed. The diary is ultimately the first and simplest form of observation (Petrogiannis, 1999, p.17).

What we consider a prerequisite for the smooth conduct of the investigation in accordance with the ethics is to ensure prisoners' privacy, anonymity, confidentiality and of course avoid any action that would constitute a betrayal and deception of the persons concerned. It is also important to ensure the informed consent of research participants because, as pointed out by Frankfort-Nachmias and Nachmias (1992, in Cohen \& Manion, 2000, p.475) when research participants are to be exposed to natural or psychological stress, informed consent must be fully guaranteed.

In this research we have taken into account all the requirements in terms of research design (Bell, 1999). The empirical research was conducted in the Judicial Prison of Korydallos and the Women's Prison in Eleonas, Thebes during the period of three months (March to May 2012). Those surveyed are two prisoners: a man in the Korydallos Judicial Prison whose initials are K.P. and a woman in the Women's Prison in Eleonas, Thebes whose initials are V.L. It should be noted that for ethical reasons (which we discussed in the previous section) the above initials are false.

\section{Validity and reliability in research}

In this qualitative study validity and reliability were ensured as follows:

1. There were two (2) telephone interviews, one of which served as a pilot study. The respondents' answers were recorded in writing and then sent to them via e-mail so that they confirm or supplement them. Their response to the questions raised by telephone confirms the validity of the research.

2. A memo was written to the respondents prisoners. The interview questionnaire was designed (which includes open and closed questions) in order to facilitate them with the written answers to the questions. The prisoners responded to the survey, an element which ensures validity and reliability. The triangulation of data on the HOU educational policy regarding prisoners was reached through the pilot telephone interview with the sociologist of the Judicial Prison and with the answers to all the questionnaire questions from the detainees. What is more, the role of triangulation that the higher distance education has on prisoners in Detention Facilities in Greece, and in particular with regard to the possibility of using the internet, is achieved with the data obtained from the telephone interview with the director of Second Chance School (S.C.S.) of Women's Prison.

\section{The survey results}

\section{Phone Interviews}

Two telephone interviews were conducted. The first, which served as a pilot, with the sociologist in Detention Judicial Prisons and the second with the director of the Second Chance Schools (SCS) Women's Prison. The questionnaire of the interviews included six open questions and a closed question. The topics of the questions concerned the existence or not of prisoners attending $\mathrm{HOU}$, the experience in distance education, the study motivation of prisoners, the 
chances of their using ICT in communicating with their Professors-Consultants, the obstacles for their attending $\mathrm{HOU}$ and ways of overcoming these obstacles.

From the telephone interviews the following data were collected.

\section{1st telephone interview: Sociologist in Judicial Prisons}

1. The experience in distance education and the attendance at HOU: There are two prisoners, one of which completed by correspondence his postgraduate studies abroad in the field of mathematics. The other prisoner was a registered student at HOU before entering prison. He had even completed three modules in the subject he is studying.

2. Prisoners' incentives for distance education: The desire of the prisoner serving life imprisonment was to continue in $\mathrm{PhD}$ as well but this did not happen since there is no possibility of PC use in the detention area, something which is prohibited by the Internal Regulation. The use of PC is only allowed for educational purposes, however, outside the detention facility (e.g. Second Chance School). The reason that the prisoner who was already a student at HOU pursued to complete his studies at HOU is that he believes that he will be able to utilize this degree in his professional career after being released. Moreover, the fact that he is a HOU student can be used in court as evidence for favouring and reducing his sentence.

3. The possibility of the experience of distance education through the use of PC: The prisoner who has studied abroad has appealed to the Ombudsman for the possibility of using a PC for educational purposes. The Ombudsman's proposal supported this request but this was not accepted by the Ministry of Justice. After he entered prison (the prisoner was already a student at $\mathrm{HOU}$ ) he faces great difficulties in continuing his studies. The use of PC is prohibited for safety reasons.

4. Communication with professors-consultants within the distance education framework: Communicating with professors-counsellors can be achieved through correspondence regarding the mailing of assignments and sometimes by phone. Professors-counsellors cannot communicate with prisoners-students in face to face meetings. Furthermore, students are not able to participate in meetings.

5. The obstacles that prisoners face during their studies in HOU and ways to overcome them: The biggest problem for the prisoner who wants to complete his studies is that while he has the opportunity to participate in the examinations conducted by HOU after completing a module, he needs special permission from the Attorney Supervisor who must take into account the risk factor of the detainee before granting the three-hour leave under police escort. Another difficulty factor in the struggle that the student-prisoner gives in order to succeed in an examination is the courts. That is, there may be a pending trial which has been scheduled for a date during the specific examinations period and which he must attend. This results in his having to repeat the module and therefore he has to pay the tuition again. This particular prisoner has applied to HOU for tuition reduction. On the other hand, the fact that he belongs in the cases of prisoners who have to go to the testing centre in handcuffs and escorted by police, as the sociologist points out, can disturb other candidates. In practice, therefore, in order for the system of examinations to be able to operate, examinations must be held within the prison, and more particularly, not under police supervision, but under the supervision for example of the professors of the Second Chance School. The examinations papers should be sent by fax to the director of the Second Chance Schools (SCS). 


\section{2nd telephone Interview: Director of Second Chance School Women's Prison}

By contacting the Director of the Second Chance Schools (SCS) Women's Prison the following data were revealed:

1. The experience in distance learning and attendance at HOU: There is a prisoner who will begin her studies at the Open University

2. The possibility of the distance learning experience through the use of PC: The prisoners are able to use a PC. There is a computer in the school principal's office, one at the secretariat and three computers in the staff room.

3. Communication with professors-counsellors in distance learning: The prisoners are able, under the control of a professor of SCS, to use the internet and email in order to access websites and to communicate with their professors via email. The prison has control of the communication. The use PC is possible with the permission of the community service.

4. The role of the Director of SCS in the possibility of the distance learning experience for the prisoners: With the initiative and recommendation of the Director of SBS at the women's prison inmates who are enrolled in higher education have the option of distance learning through the use of PC. As the director of SBS mentions specifically "it was a necessary condition... this system has been working for the past two years. On the other hand, the fact that my request has been accepted is also a matter of coincidence, and this is due to the director of the prison is a remarkable woman as well as the prison social service. In other prisons the use of PC from prisoners is considered something unnecessary, annoying, dangerous... There is no control".

5. The role of SCS in the possibility of the distance learning experience for the prisoners: C. who is studying at the Aegean University attended the SCS. She had remedial teaching at school with the help of school teachers. She sat for the university entrance examinations and passed at the University of her Choice. S. is in the 4th semester. She passed at the Technological School (TEI) of Florina. She sat for the university entrance examinations at the 3rd Lyceum of Thebes. V. who still has not started her studies at HOU is studious and comes to SVS so that she can borrow books from the school library.

6. The prisoners' incentives for attending HOU: According to the director of SCS in women's prisons Eleonas, Thebes, time in jail is "dead time." Prisoners try to pass the time through oblivion. Instead of taking psychiatric drugs, studying, reading is psychotherapy.

At the first telephone contact with the sociologist it became clear that for security reasons interviewing prisoners who belong to high-security wings was banned. It was decided that it would be better to send the questionnaire which was to be completed in writing by the prisoner who was studying at the HOU. However, a week later, and while the questionnaire had already been sent, we were informed that this prisoner had been released. This was an unexpected factor which influenced the course of the research since the following question emerged: given that the second prisoner who attends an Open University abroad has experience in distance education would he be available to answer a questionnaire on the distance learning HOU offers? Our decision to give him the questionnaire was the result of the following criteria: In the flexible or quality action plan what is important is to investigate the multiple realities. Moreover, our proposal to give him the questionnaire was a risk and a challenge for the research, which would confirm its validity and reliability.

Furthermore, all relevant stakeholders were informed in order for the Justice Department to authorize the investigation. 


\section{Written interviews results of detainees-students}

\section{The Interview}

The questionnaire of the interview of the detainees included 19 questions, which amounted to eight thematic axes. The following data emerged:

The two prisoners responded positively at completing the questionnaire. They did not answer all the questions (41 in total, 17 of which were open and 24 closed) as the questions did not meet all the needs and experiences of the prisoners. The content of the questions was related to the following topics:

- Personal data (age, years of total sentence, years of confinement, education),

- incentives for participation in tertiary distance education,

- opportunities to participate in group counselling meetings,

- communication with professors-counsellors,

- the ability to use a PC,

- the open policy of HOU,

- the importance of distance education for prisoners-students,

- the connection of SCS with higher distance education.

V.L. does not have yet experience on distance studying in HOU since she was accepted at the HOU postgraduate curriculum for the French Language in 2012. K.P. does not have any experience in distance studying at HOU since he has been attending a distance education program of a University abroad. He answered questions related to his own experience in higher distance education. Other factors that contributed in answering questions selectively are his age and sentence period.

In Greece, at the women's prison in Eleonas, Thebes, prisoner V.L. will start the HOU postgraduate distance specialization in the French Language, for the academic year 2012-2013. She is 26 years old. Her sentence is 15 years. She has been in prison for 1.5 years already. At the Judicial Prison of Korydallos prisoner K.P. attends the Denis Diderot Universite Paris 7. He began his studies in 2003. He is 68 years old. He has been sentenced to 17 times life imprisonment. He has already been in prison for 10 years.

The educational level of both prisoners is high: V.L graduated in French Literature and K.P. has a Master II in Mathematics. They also both have experience in distance education. V.L. has studied educational psychology through a distance learning program and K.P. has completed his distance education studies in Denis Diderot Université Paris 7.

Students' incentives for distance learning: A common incentive they both share in their decision to study at Open Universities is the bad psychological state in which they are, and the result of their confinement in prison. What is common is their need to employ themselves and especially their thinking in a place where their psychological balance is in danger. The director of the SCS in the Women's Prison in Eleonas, Thebes points out that "time in prison" is "dead time". They try through oblivion to make time pass. Instead of taking psychiatric drugs... studying, reading is psychotherapy".

For V.L. the motivation to continue her studies is also related to the fact that she is a fan of lifelong learning and to her need for continuous learning in order to join later (when released) the labour market. Also the facts that she is studious and interested in her scientific expertise were strong incentives in her decision to continue studies in the postgraduate level. It is a need that she had even before going to prison. 
She plans to use her studying in order to find a job in her field of preference which is associated with education (e.g. as a teacher in a public school, in language centres where she worked before entering prison, in private lessons) or even in translation offices (which she would also love).

Detainees' communication with professors-counsellors: She knows that typically she has the opportunity to participate in tutorials but she expresses her doubt whether she will ultimately have this chance given the fact that she begins attendance in September. The lack of "face to face" contact of the teachers-consultants with the prisoner-HOU student who was released is also noted by the sociologist in the Judicial Prison of Korydallos, who points out: "Teachersconsultants cannot communicate with prisoners-students in face to face meetings". Also, "they lack the opportunity to participate in tutorials".

K.P.'s communication with teachers-consultants was by mail or telephone in order to seek clarification on the assignment. Communication was not frequent (once a month until the Master) and once a semester for the doctorate he is preparing. "Face to face" communication was almost non-existent since he was only visited once in prison by a teacher-consultant. The sociologist also pointed out that "the use of PC is prohibited for safety reasons. Therefore, communication with teachers-consultants can be achieved through correspondence regarding the delivery of assignments and sometimes by phone".

Obstacles in detainees' communication with professors-counsellors: A significant barrier to communication with teachers-consultants according to K.P. is the fact that the use of PC and of the internet is prohibited. He has applied to the prison administration three times for permission to use the PC in an empty cell next to his at a specific time accompanied by a prison guard, but for security reasons the request was denied despite the positive findings of the Ombudsman to which he had appealed on this issue. K.P.'s actions on the use of PC were confirmed by the sociologist as well who points out: “... As for the possibility of using a PC for educational purposes, the particular prisoner has appealed to the Ombudsman. The Ombudsman's proposal supported this request but it was not accepted by the Ministry of Justice".

The prisoner considers the ban on the use of PC an impediment in finishing his doctorate since he is not capable of remaining update in research and in case studies that have been completed recently.

The open policy of HOU: After making a request for the first time, V.L. was accepted by lottery at HOU. She believes that there must be objective criteria in the selection of students but it would be good for prisoners to be a priority in relation to other people who are out of prison, because for these people, besides being a simple pastime and activity, the specific studies can be a source of life and hope.

The prisoner can cope with the study fees because of the support she receives from her family environment. However, she considers that it would help her on a personal level to have the opportunity to get a scholarship and, what is more, it would help the prisoners who are not able to have even the basic necessities. She also considers that the reduction of fees would be a very good move on behalf of HOU. The sociologist also notes the importance of reducing fees at $\mathrm{HOU}$, citing the prisoner-HOU student's request who, because of the difficulty he had to sit for the exams due to a trial, he had to repeat the Module and pay for it again.

V.L. has no experience of the examination system in HOU. However, the sociologist observes that the case of a prisoner going to sit for the exam in handcuffs and police escorts may agitate the other examinees, and, therefore, he suggests that the tests are taken inside the Correctional 
Facility under the supervising of SCS teachers. He also suggests the examination subjects be sent by fax to the Director of the Second Chance School (SCS).

The importance of studying at HOU: For V.L. it is of maximum importance and, more succinctly, it is a source of life.

\section{Conclusions and Discussion}

The qualitative research conducted for the first time in the Greek detention facilities has highlighted the need for distance education in prisoners.

Informing detainees about the possibility they have to attend HOU, the various departments and curricula as well as on how this is done through distance education seemed that it lacks organization and infrastructure.

For this purpose, it would be good for HOU to develop information strategy towards socially excluded people, such as prisoners. This could be developed as follows:

- The HOU website should be enriched with information on the "open" learning opportunities offered it provides to socially excluded people, such as prisoners. Even if they do not have access to the internet themselves, it is important that the information can be conveyed to them by other people (prison officials, relatives, friends, acquaintances) since according to Wilson, (2010), Pike, (2010) the opportunity for participation in tertiary distance education is related to the goodwill of those people.

- Creation of Regional - Educational Centres in areas where there are Detention Centres in order to enable the direct connection and briefing of prisoners on matters related to their course of study, the opportunities to continue their studies in the case of transfer to another prison and the opportunities for vocational rehabilitation after their release. Concerning the Open University of Great Britain, Shipley (2003, as cited in Lionarakis, 2010) points out that "the support and guidance that students receive from the network of Regional Centres as well as professors-counsellors are essential for the academic success of the institution." To better inform detainees, it would also be beneficial to provide them brochures about the HOU curricula and their attendance options.

The creation of these centres can contribute also to inform and sensitize the general public with regard to the needs of prisoners and in particular with regard to their professional reintegration after their release because, as pointed out by Mortimer (2008, p.4) "the public opinion on prisons and prisoners is inevitably fuelled by the image the media project regarding the prison environment. The man or woman in the street cannot see the reality of everyday life in prison, he or she is based solely on the stereotypical image the media forms for "life inside prison", more often presenting it gruesome and shocking".

They could also contribute to the awareness-familiarity of the prison environment (e.g., prison officials) on issues related to the lifelong education of prisoners. One reason, additionally, that prevents prisoners' access to higher education according to Wilson (2010) is that prison officials consider it an "elitist" process. Braggins and Talbot (2006) point out that it is "the envy of the penitentiary personnel for educational resources that may be available to prisoners (e.g., the fact that there is IT equipment available in small classes) while prison officials argue that their children do not have the opportunity to enjoy such privileges."

In accordance with the European Prison Rules R(89)12, distance education is provided only by mail. However, from the practice of distance education in Detention Centres it seemed that the key obstacle to the ability of prisoners to have experience in distance education is the lack of ICT 
use for security reasons. The role of SCS in Women's Prison appeared to be instrumental in overcoming this obstacle and in the implementation of the possibility of prisoners in distance education. This is an important development in prisoners' higher distance education, something which HOU should strengthen by opening "channels" of cooperation with the Detention Centres SCS.

Internet access for prisoners enrolled in tertiary distance education is a prospect which $\mathrm{HOU}$ would be advised to include in the implementation strategy of distance education for prisoners, taking into account the existing security system in Detention Centres. The case of OU/UK which implemented the POLARIS program in Detention Facilities in London as well as the development of a Virtual Campus, are good practices which could benefit HOU in the design of secure access to detainees-students online.

The role of HOU was found to be pivotal in the ability to provide educational opportunities to this target-group of socially excluded people. It is a necessity so that prisoners can deal with the conditions of their confinement on a psychological level, especially in the case of a life sentence. In the selection of higher distance education what seemed to be an important incentive for prisoners is their vocational rehabilitation after their release. The possibility of distance education is becoming necessary and urgent for the detainees who have already done some studies and choose the experience of postgraduate or lifelong education. For these reasons, prisoners could be favourably treated if they miss an examination period because of a trial, taking into account the difficulty the prisoners have on the one hand to cover the student fees and on the other the need, for psychological reasons, for examinations to take place in a location not exposed to other students (e.g., in the area of SCS which operates within detention facilities).

This is also the proposal of the Judicial Prison sociologist: "In practice, in order for the system of examinations to operate properly, examinations will have to be taken in the penitentiary and more specifically not under the supervision of the police, but under the supervision, for example, of Second Chance School teachers). Examinations papers should be sent by fax to the director of the Second Chance Schools (SCS)."

However, access to tertiary distance education is directly related to the financial burden of studying. HOU is the only institution of lifelong learning in Greece that provides distance education. A prerequisite for anyone interested in attending $\mathrm{HOU}$ is the payment of tuition fees. In the case of prisoners this is restricted due to the social exclusion they experience in prison. They have to deal with livelihood issues and the possibility of financial security of their studies is in fact impossible, except for only few cases where there is financial backing and support from the family.

An aspect of the HOU founding philosophy is the provision of "open" learning opportunities to all adults, because education is a right of all people. Therefore, it would be wise for HOU to include in its policy tuition reduction or scholarships to prisoners attending it.

The financing of prisoners in higher distance education is necessary for yet another reason: the cost of reducing recidivism of inmates costs the state less than the cost of their incarceration. According to Schuller (2010) "the total cost savings for the United Kingdom rose from 1 to $2.5 \%$ ". On a national level, therefore, it would be good to plan the financing of prisoners who wish to study in higher distance education.

Also it would be good as an indication of rewarding and recognizing of the efforts made by the prisoners in their decision to attend tertiary distance education, to calculate the HOU attendance time (as is the case in conventional universities) when favorably estimating sentence days. 
At HOU the selection of students is made by drawing lots. This effectively excludes a large number of adults from attending it. It would be wise for HOU to adopt providing "open" learning opportunities to all adults in its educational policy, especially for prisoners who recognize the vital importance of their studies.

The expansion of the HOU curriculum, with courses which meet the prisoners' educational needs "for development of practical skills and attitudes", as stated in Recommendation R(89)12 (par.5.7, p.24). More specifically, the creation of educational material that meets the prisoners' needs is a natural consequence of the HOU curriculum expansion. There is possibility of prisoners-students to build their educational profile by choosing course modules (CM) from the modular curriculum system. As Lionarakis (2010) points out, "HOU had instituted this in the founding law of 1997, but unfortunately abolished it afterwards".

Although similarly, the same issue applies in the SCS curriculum, since in the findings reported by Karidis and Fytrakis (2011) in Greek prisons it is noted that "despite the fact that the Second Chance School function in the penitentiary is valued positively, lack of appropriate resources does not allow the proper operation of educational, training or retraining programs for prisoners".

Another important aspect that arises from the research concerns the "face to face" communication of teachers-consultants with the prisoners and the latter's participation in tutorials. HOU has successfully implemented teachers-consultants' training on issues related to the effective implementation of distance education. However, access of teachers-consultants in Detention Facilities and most importantly "face to face" communication with detainees requires the acquisition of specialized knowledge. Eggleston (1991), Gehring and Hollingsworth (2002) point out that "the success or failure of a training program depends on the particular prison environment (stressful and pressing) and teachers' training (not properly equipped to deal with the reality of the prison)".

So HOU should promote the training of teachers-consultants who are interested in working with prisoners, since "in prison the teacher-counsellor of the Open University is the future for each prisoner. He is one of the few people a student meets in jail, who has no connection with the prisoner-student's past" (The Keith Jessop Award) (OU/UK Labspace, 2007).

The cooperation of stakeholders in lifelong learning has become a point of reference in national strategy as well. According to the press release (HOU, 2012), there are opportunities for cooperation between HOU and the General Secretariat for Lifelong Learning and the appropriate stakeholder for the SCS operation, the Foundation for Youth and Life Long Learning, which would be good to aim at the following points:

Cooperation of HOU with the SCS of Detention Centres: At the tutorials contact and communication with the teacher-counsellor and other fellow students is important. Prisoners are deprived of this possibility. It would be good for HOU to develop a support mechanism for prisoners (virtual classes-teleconferences under the supervision of a SCS teacher) regarding their participation in tutorials. "Face to face" communication of the professors-consultants with prisoners could be carried out at the SCS as there are specially designated areas for educational purposes and the environment is learning-friendly.

Development of a monitoring mechanism (follow up) of the progress of prisoners-students who have been released, regarding the course of pursuing their studies and their professional reintegration. Such a perspective would be useful to integrate in the actions of the Career Office of Structure Employment and Career (DASTA) of HOU. 
Finally, the cooperation of HOU with other Open Universities in the world is considered necessary in order to upgrade the curriculum offered to people experiencing social exclusion, such as prisoners.

\section{References}

1. Adams, A. and Pike, A. (2008). Security issues within prison and health ODL programmers. Retrieved 10th April, 2012, from the website: http://wikieducator.org/images/a/ab/PID_461.pdf

2. Almaliotou-Kalabaliki, G. (2011). How a 30-year-old inmate studies from within prison. Republication from Ethnos.

3. Bateman, J. (2010). Virtual Campus (Project). In Workshop A5: e-Learning platforms and Distance learning. Budapest: European Conference on Prison Education. Retrieved 16th February, 2015, from the website: http://ec.europa.eu/education/tools/llp_en.htm\#tab-5

4. Bell, J. (1999). Methodological Design of Pedagogical and Social research. Athens: Gutenberg

5. Braggins, J. and Talbot, J. (2006). Wings of Learning: the role of the prison officer in supporting prisoner education. Esmee Fairbairn. The Centre for Crime and Justice Studies. Retrieved 19th April, 2012, from the website: http:// esmeefairbairn.org.uk/news-and-

learning/publications/wings-of-learning-the-role-of-the-prison-officer-in-supportingprisoner-edu

6. Chr Breivik, P. (2010). E-learning in prison - The Norwegian IFI system. In Workshop A5: eLearning platforms and Distance learning. Budapest: European Conference on Prison Education. Retrieved 16th February, 2015, from the website: http:/ / ec.europa.eu/education/tools/llp_en.htm\#tab-5

7. Cohen, L. and Manion, L. (2000). Methodology of Educational Research. Athens: Metehmio.

8. Correctional Code N. 2776/1999 (Government Gazette A 291)

9. Costelloe, A; Langelid, T.; (contributors) Hammerschick, W; Matt, E (reviewers) (2011). Prison education and training in Europe. A review and commentary of existing literature, analysis and evaluation.

10. Council of Europe (CoE) (1989). Recommendation No. R (89)12 of the Committee of Ministers to member states on the European Prison Rules. Retrieved 17th December, 2011, from the website: http://www.epea.org/uploads/media/Education_In_Prison_02.pdf

11. Eggleston, K. (1991). Correctional Education Professional Development. In Journal of Correctional Education, 42(1), (pp. 16-22).

12. ELBEP (2011). Eliminating Language Barriers in European Prisons through Open and Distance Education Technology. ELBEP Hellenic Open University.

13. Gehring, T. and Hollingsworth, T. (2002). Coping and Beyond: Practical Suggestions for Correctional Educators. In Journal of Correctional Education, 53(3), (pp. 89-95).

14. Giossos, I.; Mavroidis, E.; Koutsouba, M. (2008). Research in distance education: review and perspectives. In Open Education - The Journal for Open and Distance Education and Educational Technology, 4(1). Retrieved 23rd December, 2011, from the website: http://journal.openet.gr/index.php/openjournal/article/view/58

15. Hellenic Open University (June, 2012). Press Release. Retrieved 2nd August, 2012, from the website: http://www.eap.gr

16. Karidis, V. and Fitrakis, E. (eds.) (2011). Criminal Confinement and Rights. The Ombudsman perspective. Athens: Legal Library. 
17. Keegan, D. (2000). The Basic Principles of Open and Distance Education. Athens: Metehmio.

18. Keogh, L. (2003). MOUS Opens Doors for Prisoners. In Journal of Correctional Education, 54(1), (p. 3).

19. Law 3879/09.21.2010: Development of Lifelong Learning and other provisions.

20. Linardatou, C. (2012). The Role of Open and Distance Education in socially excluded people. Case Study prisoners. Thesis in SSP 65. H.O.U, Available: https://apothesis.eap.gr/handle/repo/18709

21. Lionarakis, A. and Lykourgiotis, A. (1998). Open systems of higher education. In A. Kokkos, A. Lionarakis \& C. Matralis (eds.), Open and distance learning. Institutions and functions. Vol. A'. Patra: Hellenic Open University.

22. Lionarakis, A. (2010). Open Universities and Distance Universities in Europe. Two different educational outlooks in search of identity. Retrieved 6th January, 2012, from the website: http://www.edu4adults.blogspot.hu/

23. Morgan, M. and Kett, M. (2003). The Prison Adult Literacy Survey. Results and Implications. Irish Prison Service. Retrieved 12th April, 2012, from the website: http://www.irishprisons.ie

24. Mortimer, P. (2008). Higher Education in prisons: Just another chapter in the bigger picture? (EADTU). Retrieved 4th April, 2012, from the website: http://www.open.edu/openlearnworks/pluginfile.php/52819/mod_resource/content/1/E ADTU_diaporama_en_video.wmv

25. Pike, A. (2010). Building bridges across the digital divide for HE students in prison. COLMSCT Final Report. The Open University. Retrieved 9th April, 2012, from the website: http://www.open.ac.uk/opencetl/resources/colmsct-resources/pike-2010-colmsct-finalreport- $\% \mathrm{E} 2 \% 80 \% 98$ building-bridges-across-the-digital-divide-he-studentsprison $\% \mathrm{E} 2 \% 80 \% 99$

26. Robson, C. (2010). The Research of the Real World. An Instrument for Social Scientists and Professional Researchers. Athens: Gutenberg

27. Salane, F. (2008). Distance education in prisons: an educational right or a privilege? The case of "students inmates". In Distances et savoirs. Hors série. Retrieved 1st March, 2012, from the website: http://www.open.edu/openlearnworks/pluginfile.php/52823/mod_resource/content/1/Sal ane-Fanny-English-08.pdf

28. Schuller, T. (2010). Crime and Lifelong Learning: key issues Strengthening Cooperation in European Prison Education. EU Budapest. Retrieved 16th February, 2014, from the website: http:/ / ec.europa.eu/education/tools/llp_en.htm\#tab-5

29. Second Chance Schools (SDE) (2012). Retrieved 28th November, 2011, from the website: http://www.ideke.edu.gr

30. Sianou-Kirgiou, E. (2009). Open access and participation of adults in the Hellenic Open University. The need for a sociological approach to lifelong learning. In the Proceedings of 5 th International Conference in Open \& Distance Learning - November 2009, Athens, Greece.

31. Watts, J.H. (2010). Teaching a distance higher education curriculum behind bars. Challenges and Opportunities. In Open Learning, 25(1), (pp.57-64).

32. Wilson, A. (2010). Goodwill and Good fortune: Obstacles and opportunities for level 2 learners in local jails. A report to the Prisoners Education Trust. Retrieved 9th April, 2012, from the website: http://www.prisonerseducation.org.uk/resources/goodwill-and-good-fortune-obstacles-andopportunities-of-level-2-learners-in-local-jails 
The Role of Open and Distance Higher Education in Detainees in Greek Detention Facilities Charitini Linardatou, Evangelia Manousou

33. Woods, P. (1999). The methods of qualitative research. In M. Bird, M. Hammersley \& R. Common (eds.), Educational Research in Practice. Study Manual. Patra: H.O.U. 